\title{
PGR wt Allele
}

National Cancer Institute

\section{Source}

National Cancer Institute. PGR wt Allele. NCI Thesaurus. Code C51709.

Human PGR wild-type allele is located within 11q22-q23 and is approximately $92 \mathrm{~kb}$ in length. This allele, which encodes progesterone receptor protein, is involved in the establishment and maintenance of pregnancy. 